\title{
Perforin gene mutation in familial haemophagocytic lymphohistiocytosis: the first reported case from Hong Kong
}

\author{
Grace PK Chiang *, CK Li, Vincent Lee, Frankie WT Cheng, Alex WK Leung, Shinsaku Imashuku, \\ Toshihiko Imamura, Matthew MK Shing
}

\section{A B S T R A C T}

Familial haemophagocytic lymphohistiocytosis is a rare but invariably fatal disease without haematopoietic stem cell transplantation. Genetic defect identification is useful for confirming a clinical diagnosis, predicting the risk of future recurrence, and defining haemophagocytic lymphohistiocytosis predisposition in asymptomatic family members. Notably, familial haemophagocytic lymphohistiocytosis type 2 associates with mutations in the perforin gene (PRF 1 ), which is the most frequent subtype of familial haemophagocytic lymphohistiocytosis. Although perforin gene mutations have been described in Asians, they are largely reported from Japan. The case reported here is the first familial haemophagocytic lymphohistiocytosis type 2 patient in Hong Kong with an identified perforin gene mutation.
Hong Kong Med J 2014;20:339-42

DOI: 10.12809/hkmj134041

${ }^{1}$ GPK Chiang *, MB, ChB, MRCPCH

${ }^{1} \mathrm{CK} \mathrm{Li}, \mathrm{MD}$, FHKAM (Paediatrics)

${ }^{1}$ V Lee, MB, BS, FHKAM (Paediatrics)

' FWT Cheng, MD, FHKAM (Paediatrics)

${ }^{1}$ AWK Leung, MB, ChB, FHKAM (Paediatrics)

${ }^{2} S$ Imashuku, MD

${ }^{3} \mathrm{~T}$ Imamura, $\mathrm{MD}, \mathrm{PhD}$

'MMK Shing, MB, BS, FHKAM (Paediatrics)

Department of Paediatrics, Prince of Wales Hospital, The Chinese University of Hong Kong, Shatin, Hong Kong

${ }^{2}$ Division of Pediatrics and Hematology, Takasago-seibu Hospital,

Takasago, Japan

Department of Pediatrics, Kyoto, Prefectural University of Medicine,

Graduate School of Medical Science, Japan

*Corresponding author: gpkchiang@gmail.com

\section{Introduction}

Haemophagocytic lymphohistiocytosis (HLH) is characterised by fever, hepatosplenomegaly, central nervous system symptoms, cytopenia, coagulopathy, and lipid changes because of pathological immune activation, hypercytokinaemia and organ infiltration by phagocytosing histiocytes. Despite being an aggressive disease, effective treatment does exist. A treatment protocol was firstly designed in $1994^{1}$ and later revised in 2004 by the HLH Study Group of the Histiocyte Society. ${ }^{2}$ Since the implementation of the treatment protocol of HLH 1994, its 5-year survival rate has improved from around $20 \%$ to more than $50 \%{ }^{1}$

Notably, HLH is comprised of two different conditions: familial/primary HLH (FHL) and secondary HLH (Table 1), ${ }^{3}$ with the former being an autosomal recessive condition. Five mutations that lead to FHL (Nos 1-5) have now been identified and the underlying genetic defect described in four. They are: PRF1, UNC13D, STX11, and STXBP2. For genetic defect in FHL1, the potential gene locus has been identified but not the specific genetic defect. The perforin gene (PRF1) mutation is the first genetic defect described in FHL (FHL2) and accounts for $20 \%$ to $50 \%$ of all affected FHL families identified in a Japanese study. ${ }^{4}$ Perforin is a soluble, pore-forming cytolytic protein synthesised in cytotoxic lymphocytes. This molecule plays a crucial role in regulating the access of granzymes to the cytosol of target cells, where they cleave key substrates to initiate apoptotic cell death. It is sequestered, along with granzyme serine proteases, in secretory cytotoxic granules. The PRF1 mutation results in reduction of perforin protein production and its cytotoxic function. This in turn impairs the control of lymphocyte homeostasis during immune responses and leads to hypercytokinaemia and continued expansion of populations of histiocytes and activated cytotoxic lymphocytes. ${ }^{5}$ Patients without an identifiable genetic cause but with a clear familial history of $\mathrm{HLH}$ are also classified as having FHL.

The differentiation of primary and secondary HLH is notoriously difficult. The only definite way is by genetic study to find the causative mutation. In Asia, the perforin gene mutation has mostly been identified in HLH patients in Japan. ${ }^{6,7}$ The case reported here is the first and the only HLH perforin gene mutation identified in Hong Kong.

\section{Case report}

The patient was the first child in a non-consanguineous family, with no history of previous unexplained deaths in the parents' families. The child presented at 34 days of life with fever, hepatosplenomegaly, and 


\section{家族性噬血細胞性淋巴組織細胞增生症的穿透素 基因突變：香港的首宗病例報告}

蔣珮琼、李志光、李偉生、鄭偉才、梁永妿、

Shinsaku Imashuku、Toshihiko Imamura、成明光

家族性噬血細胞性淋巴組織細胞增生症 (FHL) 是一種罕見病症, 如果沒有造血幹細胞移植, 這病會致命。基因缺陷識別對確認臨床診 斷、預測未來復發的風險, 以及評估無症狀的家庭成員會否患有此症 都十分有用。二型家族性噬血細胞性淋巴組織細胞增生症（FHL2） 與穿透素基因 (PRF1) 突變相關, 它亦是這病症最經常出現的類型。 文獻中記載了亞洲人口的穿透素基因突變病例, 但大多來自日本。本 文報告本港首宗經鑑定的穿透素基因突變的FHL2患者。 pancytopenia in June 2009. The ferritin level was markedly increased to 18513 (reference range [RR], 29-333) $\mathrm{pmol} / \mathrm{L}$ and there was hypofibrinogenaemia with a level of $0.54(\mathrm{RR}, 1.85-3.83) \mathrm{g} / \mathrm{L}$. Bone marrow examination showed features of haemophagocytosis. The diagnostic criteria for HLH were therefore met. Initial magnetic resonance imaging (MRI) of the brain and cerebrospinal fluid examination were normal. Virology investigations including serology for Epstein-Barr virus (EBV), human herpesvirus 6, herpes simplex virus, and cytomegalovirus were all negative. The patient was treated according to HLH 2004 protocol with dexamethasone, cyclosporine A, and etoposide. Her clinical condition deteriorated with severe metabolic acidosis and she underwent haemodialysis. She experienced persistent neutropenia after the first dose of etoposide. Repeat bone marrow examinations showed markedly depressed granulopoiesis with residual haemophagocytic activity. Further doses of etoposide were therefore withheld while dexamethasone and cyclosporine A were continued. The first course of chemotherapy was stopped after the 11th week of treatment. However, the patient had a relapse of HLH 3 weeks after stopping chemotherapy (manifesting as fever and hepatosplenomegaly). Repeat bone marrow examination confirmed the presence of haemophagocytic activity, for which treatment with dexamethasone, etoposide, and cyclosporine A was restarted. She developed progressive metabolic acidosis ${ }^{8}$ that was once again treated by haemodialysis. Her condition then became stabilised.

Since this patient presented at early age and had a recurrence after cessation of chemotherapy, she was suspected to suffer from FHL, for which the ultimate treatment is haematopoietic stem cell transplant (HSCT). Search for a related or unrelated donor was started while the patient continued to

TABLE I. Classification of haemophagocytic lymphohistiocytosis $(H L H)$

\begin{tabular}{|c|c|c|c|}
\hline & Gene & Chromosome location & Protein \\
\hline \multicolumn{4}{|l|}{ Primary/genetic } \\
\hline \multicolumn{4}{|l|}{ Familial HLH (FHL) } \\
\hline \multicolumn{4}{|l|}{ Known defects } \\
\hline FHL 1 & Unknown & $9 q 21.3-q 22$ & Unknown \\
\hline FHL 2 & PRF1 & $10 q 21-22$ & Perforin \\
\hline FHL 3 & UNC13D & $17 q 25$ & Munc13-4 \\
\hline FHL 4 & STX11 & $6 q 24$ & Syntaxin 11 \\
\hline FHL 5 & STXBP2 (UNC 18B) & 19p13.2-3 & Munc18-2 \\
\hline \multicolumn{4}{|l|}{ Unknown defects } \\
\hline \multicolumn{4}{|l|}{ Sporadic onset associated with immune deficiencies } \\
\hline Chediak-Higashi syndrome & LYST & $1 q 42.1-q 42.2$ & Lyst \\
\hline Griscelli syndrome type 2 & $R A B 27 A$ & $15 q 21$ & Rab27a \\
\hline X-linked lymphoproliferative disorder type 1 & $S H 2 D 1 A$ & Xq25 & SAP \\
\hline X-linked lymphoproliferative disorder type 2 & BIRC4 & Xq25 & XIAP \\
\hline \multicolumn{4}{|c|}{ Other rare immune defects such as HPS-2, SCID, ITK deficiency } \\
\hline \multicolumn{4}{|l|}{ Secondary/acquired } \\
\hline \multicolumn{4}{|l|}{ Infectious } \\
\hline \multicolumn{4}{|l|}{ Autoinflammatory/macrophage activation syndrome } \\
\hline \multicolumn{4}{|l|}{ Malignancy } \\
\hline \multicolumn{4}{|l|}{ Immunosuppression } \\
\hline Metabolic & & & \\
\hline
\end{tabular}


receive chemotherapy.

While waiting for the HSCT, the patient developed tremors of the lower limbs, and bilateral ankle clonus, limb spasticity and intermittent squints (with no definite visual fixation) were noted. The developmental age regressed from 8 to 3 months, whilst brain MRI revealed diffuse parenchymal and leptomeningeal enhancing lesions suggestive of lymphohistiocytic infiltration. Cerebrospinal fluid also showed presence of pleocytosis and a lymphohistiocytic infiltrate. The patient was diagnosed to have central nervous system involvement by HLH. Three doses of intrathecal chemotherapy with methotrexate $6 \mathrm{mg}$ and hydrocortisone $8 \mathrm{mg}$ were given over a 10-day period.

The patient received an unrelated doubleunit cord blood transplant after conditioning with oral busulphan $(23 \mathrm{mg} / \mathrm{kg})$, etoposide $(30 \mathrm{mg} / \mathrm{kg})$, cyclophosphamide $(120 \mathrm{mg} / \mathrm{kg})$, and thymoglobulin $(7.5 \mathrm{mg} / \mathrm{kg})$. She had a neutropenic fever on posttransplant day 12. Donor cell engraftment was achieved on post-transplant day 16. Regrettably, she developed veno-occlusive disease causing hyperbilirubinaemia, fluid retention, progressive hepatosplenomegaly, and respiratory distress. The maximum bilirubin level was $209 \mu \mathrm{mol} / \mathrm{L}$. Despite intensive care unit treatment, intubation, and positive pressure ventilation, the patient developed respiratory failure and died on day 45 after cord blood transplant. The parents refused a full postmortem. A postmortem liver biopsy showed marked sinusoidal dilatation and congestion with atrophy of central hepatocytes. These features were compatible with sinusoidal obstruction due to veno-occlusive disease.

Genetic analysis of the patient and the parents' blood was performed, with the coding region of the perforin gene in exons 2 and 3 amplification by a polymerase chain reaction. This revealed a heterozygous one base pair deletion ( $65 \mathrm{delC}$ ) in exon 2 in the patient and her father. There was another mutation 853-855 del AAG in exon 3 of patient and her mother. Collectively, the patient had compound heterozygous mutations of the perforin gene, namely 853-855 del AAG and 65delC.

\section{Discussion}

Previously we reported our seven consecutive cases of HLH encountered from 1991 to 2006. ${ }^{9}$ Since then, there had been four other patients. Apart from showing haemophagocytosis in bone marrow or lymph node or both (Table 2), all eleven patients had fever, splenomegaly, and cytopenia in at least two cell lines. They also had markedly elevated ferritin levels with or without a raised fasting triglyceride level or hypofibrinogenaemia. The standard diagnostic criteria for HLH were met in all patients. Another teaching hospital in Hong Kong reported nine cases from 1991 to $2006 .{ }^{10}$ The overall survival of all 20 patients was $58 \%$.

Interestingly, EBV infection was confirmed (by immunoglobulin M vs EBV or EBV DNA) in 11 (55\%) of the 20 patients. The overall survival of EBV-related HLH was 55\%. In eight patients, their secondary HLH was related to malignant histiocytosis, Still's disease, and anaplastic large cell lymphoma. Two patients had X-linked lymphoproliferative disorders. ${ }^{10}$ They

TABLE 2. Clinical and laboratory parameters of Hong Kong children with haemophagocytic lymphohistiocytosis

\begin{tabular}{|c|c|c|c|c|c|c|c|}
\hline $\begin{array}{l}\text { Case } \\
\text { No. }\end{array}$ & Sex & $\begin{array}{l}\text { Age at } \\
\text { diagnosis } \\
\text { (years) }\end{array}$ & Causes & Haemophagocytosis & $\begin{array}{l}\text { Genetic test for } \\
\text { perforin gene mutation } \\
\text { performed/result }\end{array}$ & Treatment & Outcome \\
\hline 1 & $\mathrm{~F}$ & 6 & Malignant histiocytosis & BM & No & VP-16, Ara C, DNR & Died \\
\hline 2 & $\mathrm{~F}$ & 9 & Malignant histiocytosis & BM & No & None & Died \\
\hline 3 & $\mathrm{~F}$ & 1.3 & Malignant histiocytosis & BM, LN & No & VP-16, MP & Died \\
\hline 4 & $\mathrm{~F}$ & 10 & Primary EBV infection & BM & No & VP-16, Dexa, CSA & Recurrence, died \\
\hline 5 & $\mathrm{~F}$ & 5 & Malignant histiocytosis & BM & Yes/negative & VP-16, Dexa & Recurrence, died \\
\hline 6 & $\mathrm{~F}$ & 2 & Primary EBV infection & BM & Yes/negative & VP-16, Dexa, CSA & Full recovery \\
\hline 7 & M & 5 & Malignant histiocytosis & $\mathrm{BM}, \mathrm{LN}$ & No & None & Full recovery \\
\hline 8 & M & 14 & Primary EBV infection & BM, LN & No & VP-16, Dexa, CSA & Died \\
\hline 9 & $\mathrm{~F}$ & 0.1 & $\mathrm{FHL}$ & BM & Yes/positive & $\begin{array}{l}\text { VP-16, Dexa, CSA, } \\
\text { Unrelated DUCBT }\end{array}$ & Died \\
\hline 10 & $\mathrm{~F}$ & 13 & Primary EBV infection & BM & No & VP-16, Dexa, CSA & In remission \\
\hline 11 & $\mathrm{~F}$ & 12 & Primary EBV infection & BM & Yes/negative & VP-16, Dexa, CSA & Active disease \\
\hline
\end{tabular}

Abbreviations: Ara C = cytarabine; BM = bone marrow; CSA = cyclosporine A; Dexa = dexamethasone; DNR = donorubicin; DUCBT = double-unit cord blood transplant; EBV = Epstein-Barr virus; FHL = familial haemophagocytic lymphohistiocytosis; LN = lymph node; MP = methylprednisolone; VP-I6 = etoposide 
all had primary EBV infection and one had died. The other patient received a mismatched unrelated cord blood transplant and had a full recovery without recurrence.

Four patients in our unit were investigated for perforin gene mutations; only one whom had an abnormality (compound heterozygous mutations in the gene). Hence this patient is the first reported case in Hong Kong with a perforin gene mutation causing FHL.

In Asia, most perforin gene mutations of HLH patients have been reported from Japan. Ueda et $\mathrm{al}^{6}$ reported five of $14 \mathrm{HLH}$ patients with perforin gene abnormalities. The 1090-1091delCT and $207 \mathrm{delC}$ mutations of the perforin gene were frequently present in Japanese HLH patients. Ueda et $\mathrm{al}^{4}$ also reported a collaborative study which did not show PRF1 gene mutations from Korea $(n=4)$, Malaysia $(n=3)$, Hong Kong $(n=2)$, Australia $(n=1)$, and Taiwan $(n=1)$. Lee et $\mathrm{al}^{11}$ from Taiwan reported 26 HLH patients; none of whom had PRF1, Mun124, STX11, or SH2D1A mutations. There was only one case report of a heterozygous PRF1 mutation (Arg390stop) in a young Taiwanese girl who presented with a panniculitis-like T-cell lymphoma and subsequently endured fatal HLH. ${ }^{12}$

Among the 20 patients in Hong Kong, only one had a PRF1 gene mutation and two had Xlinked lymphoproliferative disorders. However, the actual rate of genetic abnormalities in HLH patients remains unknown as not all patients with $\mathrm{HLH}$ had genetic testing. This is partially due to inconsistent protocols for genetic investigations in this disease entity and inadequate laboratory support for genetic tests. Clearly, revision of the local clinical and laboratory service protocol is warranted, and more importantly, an international multicentre collaboration to improve immunological assessment and genetic analysis of HLH patients should be promoted.

\section{References}

1. Henter JI, Arico M, Egeler RM, et al. HLH-94: a treatment protocol for hemophagocytic lymphohistiocytosis. HLH study Group of the Histiocyte Society. Med Pediatr Oncol 1997;28:342-7.

2. Henter JI, Home A, Aricó M, et al. HLH-2004: Diagnostic and therapeutic guidelines for hemophagocytic lymphohistiocytosis. Pediatr Blood Cancer 2007;48:12431.

3. Freeman HR, Ramanan AV. Review of haemophagocytic lymphohistiocytosis. Arch Dis Child 2011;96:688-93.

4. Ueda I, Ghim T, Peng LH, et al. Proceedings of the 2nd Congress Asian Society for Pediatric Research; 2006 Dec 8-10; Yokohama, Japan

5. Usmani GH, Woda BA, Newburger PE. Advances in understanding the pathogenesis of HLH. Br J Haematol 2013;161:609-22.

6. Ueda I, Morimoto A, Inaba T, et al. Characteristic perforin gene mutations of haemophagocytic lymphohistiocytosis patients in Japan. Br J Haematol 2003;121:503-10.

7. Ueda I, Kurokawa Y, Koike K, et al. Late-onset cases of familial hemophagocytic lymphohistiocytosis with missense perforin gene mutations. Am J Hematol 2007;82:427-32.

8. Hui WF, Luk CW, Chan WK, Miu TY, Yuen HL. Severe lactic acidosis in an infant with haemophagocytic lymphohistiocytosis. Hong Kong J Paediatr (New Series) 2012;17:183-9.

9. Chan JS, Shing MM, Lee V, Li CK, Yuen P. Haemophagocytic lymphohistiocytosis in Hong Kong children. Hong Kong Med J 2008;14:308-13.

10. Ho MH, Cheuk DK, Lee TL, Ha SY, Lau YL. Haemophagocytic lymphohistiocytosis in Hong Kong children have a wider clinical spectrum. Hong Kong Med J 2008;14:503-4.

11. Lee WI, Chen SH, Hung IJ, et al. Clinical aspects, immunologic assessment, and genetic analysis in Taiwanese children with hemophagocytic lymphohistiocytosis. Pediatr Infect Dis J 2009;28:30-4.

12. Chen RL, Hsu YH, Ueda I, et al. Cytophagic histiocytic panniculitis with fatal haemophagocytic lymphohistiocytosis in a paediatric patient with perforin gene mutation. J Clin Pathol 2007;60:1168-9. 